Digital Press Social Sciences and Humanities

The Description of Communal Sharing on Working Wives with Work-family Conflicts (Javanese Family): Indigenous Psychology Approach

Triana Noor Edwina Dewayani Soeharto, Muhammad Wahyu Kuncoro and Sowanya Ardi Prahara

Proceeding of The 10th International Conference of Indigenous and Cultural Psychology 2019

Kwartarini Wahyu Yuniarti, Donald H. Saklofske, Rosnah Ismail, Saadi Lahlou (eds) 


\title{
The Description of Communal Sharing on Working Wives with Work-family Conflicts (Javanese Family): Indigenous Psychology Approach
}

\author{
Triana Noor Edwina Dewayani Soeharto*, Muhammad Wahyu Kuncoro, and Sowanya Ardi Prahara
}

Faculty of Psychology, Universitas Mercu Buana, Yogyakarta, Indonesia

*e-mail: winasoeharto@gmail.com

\begin{abstract}
This study aims to explore the form of communal sharing in social relations between working wives who experience work-family conflicts with husbands in Javanese families based on the indigenous psychology approach. This research was conducted in the Special Region of Yogyakarta as one of the centers of Javanese culture. The characteristics of the research respondents were the wife, who identified herself as a Javanese woman having children under the age of 12 who lived with her husband and worked as professionals. Data were collected using the exploratory method in the form of a survey with open-ended questions. The data analysis shows an overview of social relations communal sharing between working wives who experience work-family conflicts with husbands in Javanese families, which is based on the indigenous psychology approach. The forms of social relationship communal sharing between wife and husband include: husband fulfilling physical and psychological needs of the wife, husband protecting wife, husband willing to help wife, husband understanding wife, wife serving husband and children, wife managing house, educating children, supporting husband works, open and maintain family communication between husbands and wives. These findings illustrate that the nature of the relationship between husband and wife can take different forms. Providing needs, protecting or guiding the wife becomes the responsibility of the husband, while serving the husband, managing household work, and educating the child to become the responsibility of the wife. Thus, this finding describes the nature of communal sharing.
\end{abstract}

\section{Keywords}

approach, communal, indigenous, sharing, work-family

\section{Introduction}

The increasing number of Indonesian women in the workforce brings impact to the equality of men and women in marriage. Creating an equal partnership between men and women can become a way to help women to develop a positive identity (Sadli, 2010). Regarding marital status, married women with children have more positive work-family values rather than unmarried women (Grzywacz \& Mark, 2000). Women who work feel the benefits derived from several roles that are carried out such as acquiring skills, positive emotions, self-esteem, and life satisfaction (Ruderman, Ohlott, Panzer, \& King, 2002).

On the other hand, the extensive role of women in the public sector is the cause of women's problems. Married women with children receive double burdens both in the domestic and public sector (Noor, 2002). The paradigm of women's role has remained relatively unchanged, with most people still expecting women to take care of the home. On the other hand, husbands are generally expected to provide and protect the family. As an implication, working women often struggle to juggle between both roles due to getting limited support from their husbands.

Patriarchal culture is still very dominant in many third world countries, including Indonesia. Patriarchy refers to a structure that legalizes the domination of men's power on women (Koentjaraningrat, 1996). This system distinguishes the main role between men and women specifically in the family, affecting several aspects of life. Meanwhile, gender inequality emerges as an impact of the structure of society. The gender inequality makes working women are likely to have more work-family conflicts. 
Work and family conflicts are interpreted by Hill (2005), as a type of conflict both the demand of work and management of households that may influence each other. Fulfillment of roles in work-family will cause difficulties in fulfilling family-work roles (Hill, 2005; Voydanoff, 2004). Work and family conflicts have dualism i.e. work-family conflict and family-work conflict (Noor, 2004; Voydanoff, 2004).

Work-family conflict is the fulfillment of roles in the work that can cause difficulties in fulfilling roles in the family (Noor, 2004; Voydanoff, 2004). In addition, the demands of work make it difficult for workers to carry out family responsibilities (Voydanoff, 2004). Work and family become conflict because there are factors in the work that cause problems in the family (Voydanoff, 2004). Work and family conflicts usually happen when work activities affect household responsibilities.

Family-work conflict is the fulfillment of roles in the family that can cause difficulties in fulfilling roles in the work (Noor, 2004; Voydanoff, 2004). Family-work conflict occurs when problems at work collide with family responsibility. For example, activities such as maintenance of elderly parents, infants, family members with special needs, relationship problems with spouse, social relationship maintenance, and even routine household maintenance activities.

The research of Soeharto and Kuncoro (2015) found that working mothers experience work-family conflicts (i.e., workload, workplace distance, workplace conditions, work hours, work demands, relationships with coworkers, relationships with leaders). Moreover, family-work conflicts experienced by mothers are problems with their husbands, childcare, children's age, family time, family members get sick, community activities, housework, problems with assistants, and conflicts with extended families.

Workers who worked in managerial and professional fields were reported to have more work-family conflicts than those working in non-managerial and non-professional fields. Work-family conflict often occurs in workers who work in managerial and professional fields than workers who work in nonmanagerial and non-professional fields. One of the reasons is because of longer working hours (Ahmad, 2005). In addition, because the workers spend a lot of time in the office, so they lose quality time with family (Hill, 2005).

Some studies show that female workers with work-family conflicts will have a negative impact such as stress (Noor, 2001, 2002, 2004), low job satisfaction (Erdwins, Buffardi, Casper, \& O`Brien, 2001; Kim \& Ling, 2001; Noor, 2002, 2004), marital dissatisfaction, and life dissatisfaction (Kim \& Ling, 2001). Mothers with work-family conflict could be associated with a concept of social relation form by Fiske. According to Fiske (2012), there are four forms of social relations namely communal sharing, authority ranking, equality matching, market pricing. In communal sharing, every support is based on the motivation to provide welfare without expecting compensation to the family. Support is given by those with a higher power in the family towards those in a lesser position, assuming that the give and take process is considered as support by equity matching. Furthermore, social relation market pricing describes that people give support because they believe that there is a balance in relations based on the ratio or particular comparative value.

One of the important forms of social relations in family relationships is communal sharing, where a husband and a wife feel shared responsibility in meeting family needs. For example, when a wife is sick, the husband voluntarily does homework. We argue that wives also have an important role even in cases certain greater than the role of the husband. In taking care of children, for example, the wife has a greater role. The conception of garwa (wife) is not just a 'konco wingking' or as a friend who only takes care of house chores/domestic, but also interpreted as sigaraning nyawa (soulmate). The meaning of sigaraning nyawa seems clear to give a picture of a position that is parallel and more egalitarian than kanca wingking. However, the relationship between husband and wife also knows manners, one of which is sing bekti marang laki. Named Bekti if the wife can do a good job as a wife in terms of serving and helping the needs of her husband (Handayani \& Novianto, 2004).

A form of communal sharing in husband and wife relationship is based on the awareness that they are as family members consider themselves to be generally not different from each other. Their focus is general trust, and they think it's only natural to help each other. They do not separate the idea that one person has more than another because in everyone's mind share the same thing. For example, a wife works to help her husband in making money. The purpose of the study is to explore by using the indigenous psychology approach, the communal sharing relation between working wives who experience work-family conflicts with husbands in Javanese families. 


\section{Methods}

Grounded on the indigenous psychology approach, this study attempt to explore the constructs of the social relationship communal sharing between working wives with her husbands in Javanese families. Therefore indigenous psychology approach can arrange the constructs of social relations communal sharing between working wives who experience work-family conflicts with husbands in a Javanese family. The data collection method was surveyed with open-ended questionnaires as instruments. The Special Region of Yogyakarta (DIY), known as the center for Javanese culture, was used as the study location. The inclusive criteria are as follows: (1) Working mothers who identify as Javanese, (2) lives with their husbands, and (3) have children below the age of 12 who live together with them. Based on purposive sampling from various public and private organizations who live in the Special Region of Yogyakarta, 240 working mothers were selected.

In this study, qualitative data analysis was carried out to develop the instrument. The basis for creating the social relationship communal sharing scale of working Javanese wives were drawn from the themes that emerged during categorizations. The subjects' qualitative answers are categorized by the keywords, the similarity of responses, and the meanings.

\section{Result}

Based on data analysis with descriptive statistics, the categorization of social relations construction between the working wife with husband found some aspects as Table $\mathbf{1}$ and Table 2 :

Table 1 Social relations of communal sharing between wives and husbands perceived by wives with the source from the husbands

\begin{tabular}{lc}
\hline \multicolumn{1}{c}{ Form of social relations } & Total \\
\hline Physiological and psychological need fulfillment by husband & 160 \\
Husbands who are willing to help wife & 100 \\
Husbands who understand the wife & 40 \\
Husbands who protect the wife & 35 \\
\hline
\end{tabular}

Forms of social relationship communal sharing between wife and husband based on the source the from husband are physiological and psychological need fulfillment by husband (160 subjects), husbands who are willing to help wife (100 subjects), husbands who understand the wife (40 subjects), and husbands who protect the wife (35 subjects). Table 2 shows the relationship of social communal sharing between wives and husbands according to wives with the source from wives.

Table 2 Forms of social relations communal sharing between wives and husbands: according to wives with the source from wives

\begin{tabular}{lc}
\hline \multicolumn{1}{c}{ Form of social relations } & Total \\
\hline Wives serving husbands and children & 101 \\
Wives managing house & 32 \\
Educating children & 30 \\
Supporting husband works & 15 \\
Maintaining family communication & 14 \\
\hline
\end{tabular}


Form of social relationship communal sharing between wife and husband; from the wife in the form of wives serving husbands and children (101 subjects), wives managing homes (32 subjects), educating children (30 subjects), supporting husband works (15 subjects), and maintaining family communication (14 subjects).

\section{Discussion}

We can see that the subject has an understanding of both husband and wife have equal potential to build harmonious relationships. These aspects are having affection, understanding each other, and helping each other. The following will describe how the wife perceives the distribution of these potentials. First, according to the wife, the thing that is the responsibility of the husband is to fulfill the daily need physically and psychologically, to protect his wife, and to understand his wife. Second, the responsibility of the wife is to serve the husband, manage house chores, and educate the child. In communal sharing, every support provided is based on the motivation to provide welfare to the family without expecting compensation. In communal relationships, such as family and marital relations, the welfare of others is the most important. Husbands and wives want to please their partners, children, or other close relatives, to care for them and not care about themselves. Communal sharing involves selfless commitment and goes beyond economic considerations.

In Javanese family life, wives also have an important role even in certain cases greater than the husband's role. In taking care of children, for example, the wife has a greater role. The conception of Garwa's (wife) is not merely as a kanca wingking or as a friend who only takes care of domestic tasks, but also the wife also plays the role of sigaraning nyawa (life soulmate) (Handayani \& Novianto, 2004). Thus, the concept of sigaraning nyawa indicated a parallel and more egalitarian position compared to the concept of kanca wingking. Besides, the husband and wife relationship in Javanese culture also embraces the concept of sing bekti marang laki. A wife will be considered bekti when she can do a good job of providing service and assisting her husband.

Based on the ecological theory from Bronfenbrenner $(1979,2005)$, there is a link between the microsystem and the individual. Changes in each system will affect things that occur in work or family. Thus, everything that happens to one family member will affect the other family members. From the perspective of gender theory, this ability is supported by the feminine nature of women. Women can be patient and sincere and this patient and sincere nature is a feminine dimension (Handayani \& Novianto, 2004).

When facing work-family problems that have the potential to cause role conflict, women tend to be patient and sincere. Patience means having a long breath in the awareness that in time good fortune will arrive. Whereas, sincerity contains the willingness to let go of one's individuality and match itself to the great harmony of the universe as determined (Suseno, 1985). In Javanese culture that emphasizes the feminine nature of women, women will increasingly find strength since feminine traits are flexible. This can be seen in the flexibility of Javanese woman's way to solve the problem.

With this flexibility, Javanese women can adjust and overcome all situations that oppress. Besides that, the nature of nrima (accepting) in women helps women be able to react rationally and not collapse when playing several roles at the same time. The nature of nrima is also a feminine dimension (Handayani \& Novianto, 2004).

These findings illustrate that the nature of the social relationship communal sharing between wife and husband can take different forms. Providing needs, protecting, or guiding the wife becomes the responsibility of the husband while serving the husband, managing household work, and educating the child become the responsibility of the wife. Therefore, this illustrates the nature of communal sharing among Javanese working women.

\section{Conclusion}

Based on the findings, the construction of the social relationship communal sharing between working wives indicates that they experience work-family conflicts with husbands in Javanese families by using the indigenous psychology approach. In general, it can be illustrated that the nature of the relationship between husband and wife can take the form of communal sharing. 
In line with the findings, these aspects will then be operationalized to become more concrete behavioral indicators and it will be developed into items on the social relationship communal sharing scale between working wives who experience work-family conflicts with husbands. Therefore, social relations measurement for communal sharing between working wives who experience work-family conflicts with husbands is expected to be used for future measurements based on indigenous psychology approaches.

Acknowledgements: Special thanks to the research funders, Direktorat Pendidikan Tinggi has provided funding for Penelitian Dasar Unggulan Perguruan Tinggi.

\section{References}

Ahmad, A. (2005). Work-family conflict among dual-earner couples: Comparisons by gender and profession. Jurnal Psikologi Malaysia, 19, 1-12.

Bronfenbrenner, U. (1979). The ecology of human development. Cambridge: Harvard University Press.

Bronfenbrenner, U. (2005). Making human beings human: Bioecological perspectives on human development. London: Sage Publications.

Erdwins, C. J., Buffardi, L. C., Casper, W. J., \& O`Brien, A. S. (2001). The relationship of women’s role strain to social support, role satisfaction and self-efficacy. Family Relations, 50(3), 230-238. Retrieved from https://doi.org/10.1111/j.1741-3729.2001.00230.x

Fiske, A. P. (2012). Metarelational models: Configurations of social relationships. European Journal of Social Psychology, 42(1), 2-18. Retrieved from https://doi.org/10.1002/ejsp.847

Grzywacz, J., \& Mark, N. (2000). Reconceptualizing the work-family interface: An ecological perspective on the correlates of positive and negative spillover. Journal of Occupational Health Psychology, 5(1), 111126. Retrieved from https://doi.org/10.1037//1076-8998.5.1.111

Handayani, C. S., \& Novianto, A. (2004). Javanese women's power. Yogyakarta: LkiS.

Hill, E. J. (2005). Work-family facilitation and conflict, working fathers and mothers, work-family stressors and support. Journal of Family Issues, 26(6), 793-819. Retrieved from https://doi.org/10.1177/0192513X05277542

Kim, J. L. S., \& Ling, C. S. (2001). Work-family conflict of women entrepreneurs in Singapore. Women in Management Review, 16(5), 204-221. Retrieved from https://doi.org/10.1108/09649420110395692

Koentjaraningrat. (1996). Culture of Mentality and Development. Jakarta: Gramedia.

Noor, M. N. (2001). Work hours, work-family conflict, and distress: The moderating effect of spouse support. Malaysian Journal of Psychology, 15, 39-58.

Noor, M. N. (2002). Work-Family conflict, locus of control, and women`s well-being: Tests of alternative pathways. The Journal of Social Psychology, 142(5), 645-662.

Noor, M. N. (2004). Work-Family Conflict, Work-family-role salience, and women`s well-being. The Journal of Social Psychology, 144(4), 389-405.

Ruderman, M. N., Ohlott, J. P., Panzer, K., \& King, S. N. (2002). Benefits of multiple roles for managerial women. The Academy of Management Journal, 45(2), 369-386. Retrieved from https://doi.org/10.2307/3069352

Sadli, S. (2010). Different but equal : Thinking about women's studies. Jakarta: Gramedia.

Soeharto, T. N. E. D., \& Kuncoro, M. W. (2015). Construction of Instruments for Measuring Husband Support and Worker-Family Conflict in Working Mothers: Based on Indigenous Approaches. Proceedings of the 
National Seminar and Indonesian Development Psychology Association (IPPI) IX "Optimizing the Role of Families to Enhance Mental Resilience in Facing Globalization Challenges. ” Surabaya: Universitas Hang Tuah.

Suseno, F. M. (1985). Javanese Ethics: A philosophical analysis of the wisdom of Javanese life. Jakarta: Gramedia.

Voydanoff, P. (2004). The effects of work demands and resources on work-to-family conflict and facilitation. Journal of Marriage and the Family, 66(2), 398-412. Retrieved from https://doi.org/10.1111/j.17413737.2004.00028.x 